\title{
MOST COMMON COGNITIVE BIAS IN FAMILY BUSINESS MANAGEMENT
}

\author{
Yolanda Saldaña, ${ }^{1}$ Fernando Miguel Ruiz, ${ }^{2}$ Laura Leticia Gaona, ${ }^{3}$ \\ Juan Jesús Nahuat, ${ }^{4}$ Kelly Alejandra Muñoz ${ }^{5}$
}

\begin{abstract}
Due to the interaction of two incompatible systems: family and business, family business managers may have cognitive biases that result in an ineffective management. Therefore, the objective of this research study was to identify and determine the most common biases in the management of a family structure business. A documentary investigation was carried out with the purpose of compiling in a single document such biases. The analysis made it possible to conclude that the identified biases arise precisely from the interaction and incompatibility of these two systems; and that the absence of knowledge on the part of the business family and of directors of familiar companies of the presence of these biases impacts the permanence and consolidation of the familiar company.
\end{abstract}

JEL Classification Numbers: M10, M20, M50; DOI: http://dx.doi.org/10.12955/cbup.v5.961

Keywords: Cognitive bias, effective management, family business.

\section{Introduction}

The domestic family prepares their offspring to develop their life independently (Gordon \& Nicholson, 2010). The business family moves in the opposite direction to the domestic one, because it continues economically united beyond its original generation (Nogales, 2007). When a domestic family becomes an entrepreneur, its dynamics become different and complex since in the family business two divergent systems interact: family and business (Belausteguigoitia, 2010).

Often family business managers tend to lack the technical and formal skills to manage the family business effectively. They are guided primarily by intuition and family interests and do not clearly define the roles and responsibilities of family employees (Antognilli, 2009); They lack an organizational structure that is congruent with business needs and resources (Rodríguez, 2008) and give little importance to human resource practices as a means of control (Sánchez, 2012). In part, the origin of this problem is related to the distortions, perceptual flaws and defects that operate silently, which are called "cognitive biases" and that influence our actions and decisions (Libertad \& Álvarez, 2000).

Therefore, this research aims to identify and determine the most common biases in the management of a family structure business. By effective management of a family business we understand the set of operations that are carried out to direct and properly and rationally manage a family structure business with the purpose of ensuring the profitability of the company and the corporate patrimony.

\section{Literature review}

The management of a family business where the members of the different branches are the owners and, in turn, work in this one, becomes a difficult matter since the management of the company must be with rational policies and decisions (Navarro, 2008). However, there are repeated biases in the management of the same. Some of the most frequent are: Irrational management of family influence in business.

In the case of Mexico, the existence of the extended family and its growth through the inclusion of political relatives and influence peddling, exerts an increasing and considerable pressure on the family business for the following reasons: First, a profitable business is attractive to family members who even try to incorporate their political relatives, friends, and people they think they should support. Second, when we have reached the second or third generation there will be many more family members - husbands, grandchildren, grandchildren, in-laws, in-laws, etc. - who will feel entitled to be hired. Finally, there are those relatives who, because they are not well qualified, do not manage to be placed in other companies and therefore expect to be supported by a job through being part of the

\footnotetext{
${ }^{1}$ Faculty of Accounting and Management, Universidad Autónoma de Coahuila, ysalco@yahoo.com.mx

${ }^{2}$ Faculty of Accounting and Management, Universidad Autónoma de Coahuila, fernandor075@gmail.com

${ }^{3}$ Faculty of Accounting and Management, Universidad Autónoma de Coahuila, lauragaonatamez@ @otmail.com

${ }^{4}$ Faculty of Accounting and Management, Universidad Autónoma de Coahuila, jjna.2009@gmail.com

${ }^{5}$ Student, Faculty of Accounting and Management, Universidad Autónoma de Coahuila, k_2308@hotmail.com
} 
family. This becomes a dilemma for the director, because if he accepts them he jeopardizes the profitability of the business, if he rejects them, he will be violating the rules of support that govern the family (Belausteguigoitia, 1996).

Putting the interests of the family to the interests of the company

Of the 5 '144,056 companies that exist in Mexico, 3' 724, 019 are family businesses (Alcaraz, 2012). This means that more than $70 \%$ of companies in Mexico are family run and source of employment of more than 54 million Mexicans (Grant-Thornton, 2011). However, family businesses show a high failure rate. One of the causes of this problem is related to the tendency to satisfy the demands of the family without considering the needs of the organization. This is corroborated by a study by Banamex (2008) who found that for $67 \%$ of family businesses in Mexico, the family goes first. Only $33 \%$ of these businesses put the interests of the company before the family. $72 \%$ of family businesses lack policies for hiring and firing relatives; And $58 \%$ do not have a family council or hold formal meetings to address family matters related to the company.

Bias in the decision-making process

People have distortions and flaws in perception that influence silently during the decision-making process. These failures are called "biases" (Libertad \& Álvarez, 2000). One of the cognitive biases that exert the greatest influence in family business corresponds to that of emotions, which constitute a potential obstacle to logical, rational and objective decision making. "All people subjected to intense emotion can think and act wrongly, distorting reality. The impulses that originate, to a greater or lesser extent (greed, ambition, unbridled power) also influence the thinking, reflection and deliberation necessary to carry out the decision-making process "(Bonatti, 2014). In a family business, emotions permeate throughout the organization affecting not only how the business is managed but also, in the process of strategic decision making Kellermanns et al. (2014). For the decision-making is made by the family and therefore the emotional component, the emotional conflicts and the norms that govern the family influence in that process Braidot (2012).

Confusion between the norms that govern the family and those that guide the company

A rule is a line of conduct and indicates what a person should do or not, given a particular situation and what is expected. The norms that guide the behavior of the individual in the family environment are different from those that are managed in the organizational. This implies that what is expected of an individual according to family norms is opposed to what is expected of the same individual according to the principles of the organization (Gross, 2009).

In the family, two rules operate to guarantee impartiality: in vertical family relationships (parent-child relationship) the dominant norm of fairness is the concept of necessity. Parents have the moral obligation to distribute the necessary resources to meet the needs of their children. In horizontal family relationships, as it is between siblings, each individual has the right to receive equally the same resources and opportunities (Belausteguigoitia, 2010).

Transferring the roles of the family environment to the company

The set of behaviors that the person must play are called roles. Status and role are closely related. A status entails a set of roles and, for its part, the role originates from the status. The coherence between status and the roles played makes it possible for social relations to happen smoothly (García, 2011). Roles also allow you to predict the actions of others. When we interact with others, we make use of the role that is appropriate to the environment. However, experience shows us that this is not always the case. For in life it may happen that a person plays a social role in a context that does not belong to him. This is called asymmetry between the role played and the social situation that corresponds to it (O’Neil, 2006).

According to Belausteguigoitia (2007), members of an entrepreneurial family tend to interact following the same patterns that occur in the family, regardless of the context in which they find themselves. Since they transfer the patterns of behavior that are given in the family, to the company. Especially if the interaction occurs among the same members of the family. The conflict arises when we confuse the role that we must play in the house with the role that society has established to play in the company (Trevinyo-Rodríguez, 2010). The roles become blurred and conflicts arise marked by confusion. The slide of family roles to the labor scenario is reflected when: 
A) The director of a family business continues to play the role of father when the children or relatives are employed: he scolds and uses a tone of voice and words that usually correspond to a more intimate environment as it is in the family context.

B) The director does not comply with the prescribed behaviors for the role of boss, as he does not dismiss a relative for breach, the salary is not assigned according to performance, nor apply the same penalties that would apply to a non-family worker.

C) Family business directors often do not take into account their vocation and pressure them to take over the business. This behavior is more congruent with the role of the father than with the director of a company (Pelliza, 2011).

Avoiding the professionalization of the family business

There is a difference between the dynamics that are generated within a family business and a business family. The unprocessed family business is that "... in which the interactions between the family members and the company of which they are owners have not been identified, analyzed and formalized, it is usual for there to be 'traps' Or 'confusions' that are subtracting competitiveness ..." (Scerpella, 2006). In this type of family business there is no clear distinction between the economic flows of the company and those of the family; the owner believes that by the fact that they are the proprietor, they automatically acquire the capacity to direct. A confusion prevails between the bonds of affection of the family and the contractual relations in the company. The assignment of posts is based on family relationships and interests, and there is an inadequate organizational structure that responds more to the needs of the family than to the needs of the company (Vásquez, 2010).

On the other hand, the business family has achieved the professionalization of the same: the allocation of posts is based on individual competencies and not on the basis of family relationships and interests; The organizational structure is congruent with the needs of the company and not with those of the family. Succession is achieved through merit and not by kinship. Direction is objective and rational. The business has a developed management system and promotions are achieved on the basis of good performance. There is strategic planning with a clearly defined vision (Vásquez, 2010). "It is a team of people, with family ties between them, that promote the implementation of 'good practices' and the development of competitive advantages in the businesses of which they are owners, understanding that these companies are and / or will be a source of generation of value to them "(Scerpella, 2006).

\section{Conclusions}

In this paper, the most common cognitive biases that can contribute to an ineffective management of a family business were collected and described. Such biases usually operate in a hidden way and are not easy to detect, as we tend to reject any data that contradicts our opinion or belief and select only that information that ratifies what we consider correct; to overestimate our abilities, knowledge and experience; to choose to take as a reference previous experiences or information of the past and to give in to emotions, which impede the logical and rational scrutiny of the options that are best suited.

To ensure effective management of the family business the first step is to become aware of the existence of these cognitive biases and how they operate. Yet, if the present owners of family business cultivate the conviction that the business is not only of their property; but belongs to later generations and if they have the will to guarantee the livelihood and business heritage for them, it will be more feasible to the owners to make greater use of a logical reasoning in order to reduce the impact of such bias on the management of the family business.

\section{References}

Alcaraz, R. (2012)., Empresas familiares o familias emprendedoras. En Grandes PYMES Octubre 31. Available at: http://familiasemprendedoras.wordpress.com/2012/10/31/empresas-familiares-o-familias-emprendedoras/\#more-219

Antognilli, S. (2009). Los recursos humanos en empresas familiares. En Herramientas para Emprendedores. Available at: http://www.gestiopolis.com/innovacion-emprendimiento/recursos-humanos-en-empresas-familiares.htm

Banamex (2008). Encuesta de empresas Familiares en México. Informe de Resultados. Available at http://www.mejoresempresasmexicanas.com/blog/wp-content/uploads/2011/03/Resumen-Empresas-Familiares-.pdf Belausteguigoitia, I. (1996). La relación familiar en las organizaciones mexicanas. En Revista Adminístrate Hoy-La Práctica en la Micro, Pequeña y Mediana Empresa. Octubre 1996. Año 3 No. 30.

Belausteguigoitia, I. (2007). Principales causas de conflicto en las empresas familiares. Available at: http://cedef.itam.mx/sites/default/files/u489/causasdeconflictoenlaempresafamiliar.pdf 
Belausteguigoitia, I. (2010). Empresas Familiares. Su dinámica, equilibrio y consolidación. ${ }^{a}$ Ed. México: Mc Graw Hill. Bonatti, P. (2014) Los sesgos y las trampas en la toma de decisiones. En: U.B.A. Facultad de ciencias Económicas. Available at:

http://www.econ.uba.ar/www/institutos/epistemologia/marco_archivos/ponencias/Actas\%20XIII/Trabajos\%20Episte/BONA TTI_trabajo.pdf

Braidot, N. (2012) Toma de decisiones: el rol de las emociones en la empresa familiar. En Fórmula Negocios. Available at: http://www.formulaenlosnegocios.com.mx/toma-de-decisiones-el-rol-de-las-emociones-en-la-empresa-familiar/

García, A. (2011). El conflicto de roles entre los intervinientes y gestores de situaciones de emergencia. En Repositorio Universidad da Coruña. IV Jornada sobre gestión de crisis. 85-97. Available at: http://ruc.udc.es/dspace/bitstream/2183/13143/1/CC-118_art_4.pdf

Grant-Thornton, S. (2011). Empresas familiares. Available at: http://ssgt-correos.blogspot.com/2011/03/empresasfamiliares.html

Gordon, G., \& Nicholson, N. (2010) Family Wars. Stories and insights from famous family business feuds. London: Kogan Page.

Gross, M. (2009). Las Normas sociales en el comportamiento de los grupos. Available at:

http://manuelgross.bligoo.com/las-normas-sociales-en-el-comportamiento-de-los-grupos

Libertad, M., Álvarez, A. (2000). Sesgos cognoscitivos del gerente: su influencia en la toma de decisiones. En Rev. Cubana Salud Pública. Vol. 26 (1): 5-11. Escuela Nacional de Salud Pública. La Habana. Cuba. Available at:

http://scielo.sld.cu/scielo.php?pid=S0864-34662000000100001\&script=sci_arttext

Kellermanns, F., Dibrell, C. and Cruz, C. (2014). The role and impact of emotions in family business strategy: New approaches and paradigms. At Journal of Family Business Strategy.

Vol 5, Issue 3. Available at: http://www.sciencedirect.com/science/article/pii/S1877858514000539

Navarro, K. (2008). Estado actual de la investigación sobre la gestión del conocimiento en empresas familiares. Revista de Ciencias Sociales Vol. XIV, N 1, pp. 30 -45. Available at:

http://www.scielo.org.ve/scielo.php?script=sci_arttext\&pid=S1315-95182008000100004\&nrm=iso\&tlng=pt

Nogales, F. (2007) Las culturas familiares: gestión clave para la cohesión y continuidad de las familias empresarias. En la empresa familiar y los nuevos retos de gestión. Available at:

http://media.eoi.es/nw/Multimedia/PublicacionesEOI/2007_Libro_19.pdf

O’Neil, D. (2006). Status and Role. En Social Organization: An Overview of How We Create and Maintain Social Groups. Available at: http://anthro.palomar.edu/status/stat_2.htm

Pelliza, O. (2011). Conflictos en la empresa familiar. Animarse a otra versión. Available at: http://www.ciges.org.ar/documentos/Conflictos\%20en\%201a\%20Empresa\%20Familiar.pdf

Rodríguez, G. (2008) Los Recursos Humanos en la Empresa Familiar. http://www.recercat.net/bitstream/handle/2072/13827/TFC-RODRIGUEZFORNOS-2009.pdf?sequence=1

Sánchez, G. (2012). La gestión socio-emocional de recursos humanos en la empresa familiar. En La Opinión. Available at: http://www.um.es/cef/joomla/index.php?option=com_content\&view=article\&id=1941:la-gestion-socio-emocional-derecursos-humanos-en-la-empresa-familiar\&catid=20:colaboraciones-sobre-la-ef \&Itemid=41

Scerpella, L. (2006). De "empresa familiar" a "familia empresaria". The World Leadership. ISEAD on line school. Available at: http://www.degerencia.com/articulo/de_empresa_familiar_a_familia_empresaria

Trevinyo-Rodríguez, R. (2010). Empresas Familiares. Visión Latinoamericana. Estructura, gestión, crecimiento y continuidad. México: Pearson \& Prentice Hall.

Vásquez, J.M. (2010). ¿Empresa familiar o familia empresaria? MBA \& Educación Ejecutiva. Available at: $\mathrm{http}: / / \mathrm{mba}$.americaeconomia.com/articulos/reportajes/que-diferencia-una-empresa-familiar-de-una-familia-empresaria 